\title{
Village Government Policy on Tourism Management in Situngkir Village
}

\author{
Agung Suharyanto $^{1}$, Ayu Febryani ${ }^{2}$, Wiflihani $^{3}$, Beby Masitho Batubara ${ }^{4}$ \\ \{agungsuharyanto@staff.uma.ac.id ${ }^{1}$,ayufebryani@unimed.ac.id ${ }^{2}$, wiflihani@unimed.ac.id ${ }^{3}$, \\ beby@staff.uma.ac.id $\left.{ }^{4}\right\}$ \\ Universitas Medan Area, Jalan Kolam No. 1, Medan Estate, Indonesia 1, 3, 4, \\ Universitas Negeri Medan, Jalan Willem Iskandar, Pasar V, Medan Estate, Indonesia ${ }^{2}$
}

\begin{abstract}
This study aims to determine government policies that affect tourism, the role of village governments in tourism development, the relationship between village governments and capital owners and the use of traditional home homestay as Lake Toba tourism icons in Situngkir Village. The research used was a qualitative descriptive study and the location of this study was in Situngkir Village, Pangururan District, Samosir Regency. Data collection is carried out in research using observations, interviews, and documentation as data collection techniques. Based on the results of research that in the Situngkir Village there is a village government system policy that affects tourism, the role of the village government in fostering tourism in the community and maintaining the relationship of the village government with capital owners for the development progress and the economy of the community in the tourism area. In terms of the use of traditional home homestays as tourism icons that have not been maximized, which of course government policy here is urgently needed to develop the progress of tourism and the community's economy.
\end{abstract}

Keywords: village government policy, management, tourism.

\section{Introduction}

Murphy [1] revealed that Indonesia is a country that has a wide variety of types of tourism, for example natural, social and cultural tourism which is spread from Sabang to Merauke. In addition to saving its natural attractions, Indonesia also has cultural tourism as evidenced by the many historical relics and various customs that are still inherent in every Indonesian society. The diversity of arts and cultural customs of Indonesian people that attract local and foreign tourists, so that with the potential that is owned, making Indonesia one of the tourist destinations. Indonesia, which has abundant cultural diversity and tourism, can overcome the fundamental problem by strengthening the economy from the addition of regional income. Through this, as a country that has abundant diversity, Indonesia can develop its potential for example in terms of tourism.

This is because tourists visiting Indonesia, both those who only enjoy the beauty of Indonesian tourism and who enjoy the diversity of their customs can make Indonesia a country known in the world for its tourism. Tourism is also an industry whose survival is largely determined by the pros and cons of the environment. Therefore, the development of tourism must pay attention to the preservation of environmental quality, because in the tourism industry the environment is utilized. The existence of the tourism area has both positive and 
negative impacts on the relationship of human interaction with the environment, the socioeconomic conditions of the community, and the cultural changes of the local community.

Lake Toba is no stranger to the ears of the people of Indonesia, even the world. The area of the largest volcanic lake with the island of Samosir is known for its legendary story that has been handed down throughout the archipelago. From this condition, the government has established Lake Toba as the National Tourism Strategic Area (KSPN) and has become 10 (ten) national tourism destinations which have become development priorities. Referring to the statement of the Head of the Authority, Arie Prasetyo quoted from various national media, the Government wants to make Lake Toba a tourist area with a modern concept [2] (www.compasiana.com). This makes that the impact of tourism, both positive and negative as well, ultimately takes place in the Lake Toba tourism area.

The government which is in the tourism area certainly has a great responsibility for these conditions. Situngkir village is one of the tourist villages because it is included in the Lake Toba pass. However, in Situngkir village there are natural problems caused by the development carried out by the government. The government intends to aim at developing tourism in the Situngkir village, but that harms the natural resources that surround the development. There is a lot of infrastructure development in the tourism area in Situngkir village, which just doesn't work, so there is an impression of spending money on useless things. The construction of the pier which should have been able to make things smooth for visitors did not function properly, because it was not calculated properly. Events like this, are often not well thought out by the government so that when they have been implemented, there is no thought for the continuation of infrastructure development. Other development impacts also occur, so that sometimes they do not pay attention to the condition of the natural environment as part of the tourist attraction itself. The impact of development like this should be the focus of the government when making policy in making decisions.

Situngkir village already has a good government system in regulating and preventing natural damage caused by the development of government aimed at improving its tourism system. In this village, there are government policies that pay attention to the development of tourism. Policies taken related to development must have several conditions so that natural resources are not damaged and the community can benefit from the policy. The government system that aims to increase tourism by not destroying nature is the picture of the government system in making policies in Situngkir village.

The research that is relevant to this research is Septiarani [3] with the research title "Understanding the village Government System" in his research explained that the government makes a village into new autonomous regions which are seen in terms of the expansion of the region and also reveals how the failures that have been experienced government in carrying out the management of an area and is not consistent with the structure of the established government system. Other relevant research was carried out by the North Sumatra Province Research and Development Agency [4] on "Utilization of Traditional Home as Homestays in the Lake Toba Area in North Sumatra".

The results of the study revealed that the number of traditional houses as homestays that have been utilized for improving the community's economy, cultural and social preservation of the community, and has been managed by Pokdarwis for Samosir regency as many as 84 houses; Toba Samosir regency has 3 houses; Humbang Hasundutan regency with 4 houses; and North Tapanuli regency with 25 houses. This research focuses more on Situngkir village government system policies that affect tourism; the role of the village government in fostering tourism in the Situngkir village; and the relationship between the village government and the capital owners in Situngkir village. 


\section{Research method}

The type of research in this study is qualitative with a descriptive approach. Thus, the research report will contain excerpts to illustrate the presentation of the report. The data comes from interview scripts, field notes, personal documents, notes or memos, and other official documents. By choosing this approach the data obtained in the form of behavior, speech, activities and other actions that take place in an application of the method during the learning process takes place (Moleong) [5]. The presentation of the data obtained from the information is explained appropriately by not eliminating the nature of scholarship. In this research, it is intended to be able to describe in a straightforward and detailed role of the government in developing tourism in the Situngkir village.

The research location was Situngkir village, Pangururan District, Samosir regency. Situngkir village is a division of Samosir Regency where previously there was only one village but now there are five villages. This village was chosen as a research location because it is one of the areas around Lake Toba and the government is currently developing tourism potential in this village. Suyanto [6] explained that the research subjects would be informants who would provide various kinds of information needed during the research process. In this study include two kinds of informants, namely key informants (research subjects), and additional informants.

Key informants are residents who know, have a variety of basic information needed in research, and are directly involved in the social interactions under study. While additional informants are people who can provide information even though they are not directly involved in the social interactions under study. In qualitative research, the determination of research subjects is more selective, to build theoretical generalizations. Data collection techniques in this study are observation, interviews, and documentation. Sugiyono [8] states that observation is the basis of all science. The observation was carried out directly at the research location by observing the subject and object of research.

Eisenberg in Sugiyono [9] states that the interview is a meeting of two people to exchange information and ideas through questions and answers, so that meaning can be constructed in a particular topic. In this research data collection was carried out directly through in-depth interviews with informants. Documentation is a data collection activity by recording and documenting research subjects and objects. In this study, researchers conducted data collection by taking pictures and recording during interviews with informants.

\section{Result and discussion}

The government in an area has a different system. The system of government between one country and another may or may not be the same. It all depends on how the situation and conditions of the area concerned. Likewise, the existing government system in Situngkir village, namely the existing government system in Situngkir village is determined under the needs of the village, its objectives and can solve problems in the village. With the development of rural tourism development, there will be a flow of urbanization to rationalization (city people are happy to go to the village for recreation).

In the government system in Situngkir Village, the decision is taken by the government, in which there is a process of mutual influence affecting as a result of a total and reciprocal normative relationship between the village government, the central government, and the 
community. All government policies must have a contribution to tourism because the village of Situngkir is a tourism village which has abundant natural resources, one of which is the Parbaba White Sand Beach tour. Therefore, the village government is very considering all decisions on tourism.

From interviews with informants, it can be seen that the influence on tourism in Situngkir Village is the existence of policies that pay attention to the environment in the development of tourism, meaning that development made by village governments must be under the environment and natural resources available. Furthermore, there is cooperation between the village government and the community and the respective functions of the community and village government in the progress of Tourism. On the other hand, the community also has an important function and role in the policy. The village government system is very influential in tourism. This is indicated by the existence of a village fund policy that includes tourism programs in its decisions.

The role of the village government in developing tourism objects is an absolute requirement in advancing the tourism potential of the village. Based on Government Regulation of the Republic of Indonesia No 72 of 2005 concerning Villages article 15 [10], the Village Government is obliged to manage the potential of the village in the context of achieving the objectives of laying out authority in the implementation of village autonomy, the objectives include: improving people's welfare, equity, and justice, democracy and respect for culture local, pay attention to the potential and diversity of the region [11]. Based on these regulations, it can be explained that the role of the village government is not only to exercise village autonomy but also the obligation to manage the potential of existing villages so that there is prosperity in the community [12].

Potential villages in the Situngkir Village are tourism. One of the tourist attractions developed is Parbaba White Sand Beach. The role of the village government which is very important in developing the potential of the Parbaba White Sand Beach is a party that has authority in the regulation, supply, and allocation of various infrastructure related to tourism needs. Not only that, but the village government is also responsible for determining the direction to travel on. The government also facilitates existing tourist objects to increase the flow of tourist visits.

The role of regional heads in developing the potential of Parbaba White Sand Beach is inseparable from the cooperation of village officials with local communities. This is because the community and village government have their respective functions and roles in the progress of tourism. Besides, the government also pays attention to the private sector who wants to establish a business in the area of tourist attractions, so that they continue to pay attention to the conditions and environment of the tourist area. The other role of village governance in the progress of tourism in this village is to consider tourism in every decision such as the design of village fund expenditures.

Good governance policies must consider tourism; therefore, tourism is one of the objects in the design of village fund expenditures. Some communities also stated that the government had made a cultural program which was held every Saturday and the participants were students who attended school in Situngkir village and from outside the village. This is done by the Regency Government to attract tourists from outside the area to know the culture in Situngkir village. The event that was held was intended to attract the sympathy of tourists because recently the number of tourists visiting the Situngkir village was quite declining due to the sinking incident of the KM Sinar Bangun ship.

Based on the findings in the field, data are obtained that the relationship between the capital owner and the village government in developing projects is not good if the project is 
built outside the agreement. For example, it is the construction of the Jetty project that was carried out at a suboptimal level and according to appropriate standards. This is indicated by the fact that the newly built pier that has not yet been officially opened has started to break down and make visitors feel insecure and afraid of being in that position. Even though the budget spent is large enough to build the pier. As for facilities that have started to break down, such as the steps, especially when the lake waves rise and strong winds, the jetty feels shaking so residents who visit feel frightened by this. Even though these conditions have been repeatedly reported by journalists/reporters and also non-governmental organizations, no action has yet been taken to repair the jetty.

If viewed in terms of tourist attractions, the government has played a role in the development of road infrastructure in this village that has been well ordered. Although, it is still easy to find rubbish littered at tourist sites. So far, the cleanliness facilities at the Parbaba White Sand Beach such as brooms, garbage cans, are purely provided by the tour operators themselves, not from the Village Government. This is all done independently by the village community and capital owners in the tourist area, for example, a garbage cart that the manager hires privately, by each time transporting trash, pays Rp. 200,000, -.

Lake Toba is one of 10 priority destinations that have great tourism potential. The potential for beautiful nature is a driving force for tourists to visit. Distinctive local cultural potentials are the main attraction of Lake Toba tourism, including traditional houses, cultural reserves, arts, traditional ceremonies, traditional dances, and various cultural activities. The community has also begun to provide positive responses related to tourism development, although not yet fully open and seem difficult to accept foreign cultures.

In Situngkir Village, various community-managed homestays have been integrated with local wisdom activities in their promotional packages. Although there are various weaknesses in the management of traditional houses as a homestay. Some weaknesses lie in the local community who tend not to know storytelling about the history of traditional houses/legends/local folklore. Besides, the local government also has not made promotions related to homestays on online portals and has not been integrated with other homestays in the area around the village. Besides, homestay managers have not been given training on the development of ASEAN-standard homestays by the government as a whole and continuously.

Traditional houses as homestays also do not yet have adequate facilities, such as there are no markers/guide, ATM availability, money changers, culinary (kosher), cleanliness, and other things. Infrastructure is also not optimal, such as the availability of transportation modes, clean water, and so on. The tourist registration system is also not integrated directly with the village government so that it cannot be obtained quickly due to the number of tourists visiting Situngkir Village. Many homestays have not been connected to open access related to promotions. However, through the existence of a homestay, it can be a source of additional income for the local community.

The homestay that uses traditional houses as a place to stay for tourists (mostly foreign tourists) is an effort to preserve traditional houses so that they are increasingly recognized internationally and efforts to preserve and promote the culture of the local community. Besides, it can be a great potential for village governments in developing rural tourism and other tourism (religious tourism, educational tourism, cultural tourism, culinary tourism, agrotourism, and so on). Through homestay development, it is expected that the community around the homestay must be prepared to accept the arrival of cultural patterns from outside (must be extroverted).

Besides, the young generation of Situngkir Village, who have completed education in the city, must be ready to go back and build their villages under the philosophy of the Batak 
people, that is the marsipature. The local community must also change the orientation attitude served (in the context of adat) to serve guests (in the context of business). The community is also demanded to develop hospitality capabilities. Village and local governments must also be able to create homestay with international standards while still promoting local culture. The government must also provide homestay management to be able to become a homestay with ASEAN/International standards. These things are a form of consistency in developing tourism in the Lake Toba region.

\section{Conclusions}

The policy of the village government towards tourism in Situngkir Village is to pay attention to the environment in tourism development, develop traditional home homestay as cultural promotion, and supervise work/project results according to work agreements. The community is also expected to be always concerned with tourism on Lake Toba so that they can jointly maintain the preservation of nature in the Lake Toba region in general, and the Situngkir Village in particular. The growth of tourists is expected to increase from year to year, of course, accompanied by improved facilities and infrastructure of the tourist area, in this case, Lake Toba. Therefore, the growth of accommodation is also a reference for the local government, so that accommodation that is not feasible, can immediately get improvement and improvement.

\section{References}

[1] Murphy. Tourism A Community Approach. London and New York, 1985.

[2] www.compasiana.com

[3] Septiarani, Alfinanta. (2017). Memahami Sistem Pemerintahan Desa. 1-60.

[4] Sitorus, Jonni, dkk. 2019. Pemanfaatan Rumah Tradisional sebagai Homestay di Kawasan Danau Toba di Sumatera Utara [hasil penelitian]. Badan Penelitian dan Pengembangan Provinsi Sumatera Utara.

[5] Meleong, Lexy. J. Metodologi Penelitian Kualitatif. Bandung: Remaja Rosdakarya, 2000.

[6] Suyanto, Bagong. Metode Penelitian Sosial, Kencana Prenada Media Group, Jakarta, 2005.

[7] Ritzer, Goerge \& Goodman, F.J.. Teori Sosiologi Modern, Jakarta: Prenada Media, 2004.

[8] Sugiyono. Metode Penelitian Kuantitatif Kualitatif dan R\&D. Bandung: Alfabeta, 2010 .

[9] Sugiyono. Metode Penelitian Kuantitatif Kualitatif dan R\&D. Bandung: Alfabeta, 2010.

[10] Peraturan Pemerintah No. 72 Tahun 2005 Tentang Desa.

[11] Undang-Undang No. 32 Tahun 2004 Tentang Pemerintahan Daerah.

[12] Simamora, R.K., dan Rudi Salam Sinaga.. Peran Pemerintah Daerah dalam Pengembangan Pariwisata Alam dan Budaya di Kabupaten Tapanuli Utara, Jurnal Ilmu Pemerintahan dan Sosial Politik, 4 (1): 79-96, 2016. 